Article

\title{
The Hazardous Status of High Density Sludge from Acid Mine Drainage Neutralization
}

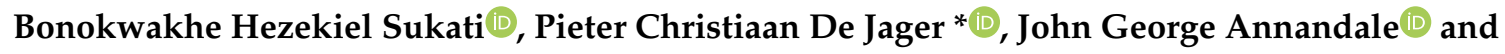 \\ Philip Dale Tanner \\ Department of Plant and Soil Sciences, University of Pretoria, X20, Hatfield 0028, South Africa; \\ bonokwakhesukati@yahoo.com (B.H.S.); john.annandale@up.ac.za (J.G.A.); philtanner@mweb.co.za (P.D.T.) \\ * Correspondence: chris.dejager@up.ac.za; Tel.: +27-124203216
}

Received: 2 October 2018; Accepted: 8 November 2018; Published: 13 November 2018

check for updates

\begin{abstract}
Classification of waste is an essential part of waste management to limit potential environmental pollution; however, global systems vary. The objective was to understand the waste classification of high density sludge (HDS) from acid mine drainage (AMD) treatment, according to selected global systems. Three sludges from two limestone treatment plants, and three others from a limestone and lime treatment plant from the Mpumalanga coalfields of the Republic of South Africa (RSA) were evaluated. Systems for the RSA, Australia, Canada, China, and the United States Environmental Protection Agency (USEPA) were considered. The USEPA system rated all six sludges non-hazardous, Canadian and Chinese systems allocated a hazardous status to one sludge from the limestone treatment plants based on Ni solubility. The RSA system considered two of the sludges from limestone treatment plants to be higher risk materials than did the other countries. This was due mainly to the RSA system's inclusion of Mn and use of appreciably lower minimum soluble levels for $\mathrm{As}, \mathrm{Cd}, \mathrm{Pb}, \mathrm{Hg}$, and Se. None's use of lime resulted in higher soluble Mn. Minimum leachable concentration thresholds for $\mathrm{Cd}, \mathrm{Hg}, \mathrm{Pb}, \mathrm{As}$, and $\mathrm{Se}$ in the RSA system were below method detection limits for Toxicity Characteristic Leaching Procedure (TCLP) extracts, making the guidelines impractical, and revision is advised. Considering all the systems, the probability that the HDS from the coalfields of Mpumalanga, South Africa will be classified as hazardous waste increases if the material is only subjected to limestone treatment because of Ni solubility.
\end{abstract}

Keywords: waste; classification; AMD; HDS; TCLP

\section{Introduction}

Neutralization of acid mine drainage (AMD) with lime $\left(\mathrm{Ca}(\mathrm{OH})_{2}\right)$ or limestone $\left(\mathrm{CaCO}_{3}\right)$ through conventional processes generates an inorganic solid, semi-solid or liquid waste referred to as sludge $[1,2]$. If the sludge is recycled and mixed with lime or limestone prior to AMD addition high density sludge (HDS) is generated [3-7]. Acid mine drainage is a mine impacted solution generated by the exposure of sulphide minerals (e.g., pyrite- $\mathrm{FeS}_{2}$ ) to water, oxygen, and catalytic bacteria (Thiobacillus ferrooxidans) [8-10]. The solution can be extremely acidic ( $\mathrm{pH} 2.0$ to 4.0) and contains transition metals and metalloids which can be toxic to the receiving environment. The treatment of AMD is therefore needed to neutralize its acidity and remove/precipitate these metals and metalloids from solution. In the case of transition metals, often as hydroxides by raising its $\mathrm{pH}$ to $>10.5$. The by-product (HDS) generated consists of gypsum $\left(\mathrm{CaSO}_{4} \cdot 2 \mathrm{H}_{2} \mathrm{O}\right)$ and iron oxides $[1,11]$. There are other processes focused at limiting pollution and environmental risk of mines that also generate gypsum, for example flue gas desulfurization (FGD) process aimed at controlling sulphur dioxide $\left(\mathrm{SO}_{2}\right)$ emissions during the combustion of fuel fossils. Flue gas desulfurization process facilitates dewatering of the sludge generated and encourages gypsum crystallization [12,13]. However, what makes HDS 
different is the appreciable iron oxide content and transition metals are often partitioned with the iron oxide fraction.

High density sludge solids content range from 15 to $70 \%$ (with dry bulk densities of 1050-1370 $\mathrm{kg} \mathrm{m}^{-3}$ ) compared to $5 \%$ solids for sludges from conventional methods [4,14]. The higher density is obtained through the recycling of sludge which promotes the precipitation of more solids by providing surfaces for heterogeneous nucleation (which catalyze precipitation) $[4,15]$. This concentration of solids can unintentionally increase the risk of HDS to be classified as hazardous waste because of high content and/or solubility of some of its constituents (e.g., $\mathrm{Ni}, \mathrm{Mn}, \mathrm{Hg}, \mathrm{Pb}, \mathrm{Se}$, As) $[3,6,16]$.

Large volumes of HDS are generated daily and often stored in disposal facilities [6,17]. Maree et al. [17] pointed out that an estimated 20 tons of HDS is produced from each megaliter of AMD neutralized. For the coalfields of Mpumalanga, a discharge of $360 \mathrm{ML}^{-1 a y}{ }^{-1}$ AMD is predicted [5,18-22] translating to 7200 tons of HDS per day. If all this HDS is to be considered hazardous, this would have enormous logistical, cost, and environmental implications for operating mines and the government.

Assessment of the risk HDS poses to the environment (soils, ground, and surface water) and to human health is critical. Risk assessment often includes various steps, for example, hazard identification, dose-response assessment, exposure assessment, and risk characterization [23,24]. However, this study focuses on waste classification, an important part of a risk assessment where the elemental make-up and solubility of the elements in the waste are determining. In general, waste classification systems are based on the solubility of specific constituents $[25,26]$. The chemical composition of the waste depends on the chemistry of the AMD neutralized and the efficiency of the neutralization process $[5,6,27]$.

The aim of the study was to investigate the classification of HDS from the neutralization of AMD from the Mpumalanga Coal Fields in South Africa using the waste classification systems of Australia, Canada (Ontario and Manitoba, British Columbia and Alberta), China, and the United States of America (USEPA). This was also done to ascertain if South African guidelines are perhaps too conservative, or indeed, too lenient.

\section{Materials and Methods}

\subsection{Chemical Characterization of HDS Products}

To achieve the objectives, total concentration (TC) determined using X-Ray fluorescence (XRF) and leachable concentration (LC) data determined using Toxicity Characteristic Leaching Procedure (TCLP-1311) for HDS products (inorganic solid wastes) were obtained from literature and from collieries in the South African Coalfields, Mpumalanga Province, eMalahleni (Witbank) (Table 1). Data for Limestone-Site 1, an HDS Plant that uses limestone alone to treat AMD (coordinates; $25^{\circ} 46^{\prime} 32.67^{\prime \prime} \mathrm{S}, 29^{\circ} 04^{\prime} 43.53^{\prime \prime}$ E) was obtained from our own chemical characterization, done at the University of Pretoria. Data for Limestone-Site 2, an HDS Plant that also uses limestone alone to treat AMD was obtained from a South African Water Research Commission (WRC) report [17]. While the data for the Limestone $\left(\mathrm{CaCO}_{3}\right)$ plus Lime $\left(\mathrm{Ca}(\mathrm{OH})_{2}\right)$ Site was obtained from Anglo American Report [18]. 
Table 1. Sources of data used for HDS.

\begin{tabular}{|c|c|c|c|}
\hline Site & HDS & Sludge Characterization & Sources of Data \\
\hline $\begin{array}{c}{ }^{1} \text { Limestone } \\
\left(\mathrm{CaCO}_{3}\right)-\text { Site } 1 \\
\end{array}$ & $\mathrm{HDS}_{\mathrm{CaCO}_{3}}$ & HDS-Mainly Gypsum with Fe oxides (own characterization) & This study \\
\hline \multirow{2}{*}{$\begin{array}{c}{ }^{2} \text { Limestone } \\
\left(\mathrm{CaCO}_{3}\right)-\text { Site } 2\end{array}$} & $\mathrm{HDS}_{\mathrm{CaCO}_{3}} 1$ & $\begin{array}{l}\text { HDS-Mainly Gypsum with Fe oxides, high environmental risk, } \\
\text { deposited in a lined pond to prevent leaching of metals }\end{array}$ & \multirow{2}{*}{ [17] } \\
\hline & $\mathrm{HDS}_{\mathrm{CaCO}_{3}} 2$ & $\begin{array}{l}\text { HDS-Mainly Gypsum with Fe oxides, low environmental risk, } \\
\text { deposited in a large area, leaching not a concern }\end{array}$ & \\
\hline \multirow{3}{*}{$\begin{array}{l}\text { Limestone }\left(\mathrm{CaCO}_{3}\right) \text { plus } \\
\quad \text { Lime }\left(\mathrm{Ca}(\mathrm{OH})_{2}\right) \text { Site }\end{array}$} & $\mathrm{HDS}_{\mathrm{Ca}(\mathrm{OH})_{2}} 1$ & HDS-Mainly Gypsum with Fe \& Mn oxides & \multirow{3}{*}{ [18] } \\
\hline & $\mathrm{HDS}_{\mathrm{Ca}(\mathrm{OH})_{2}} 2$ & HDS (Fine textured)- $90 \%$ Gypsum and $10 \%$ Brucite $\left(\mathrm{Mg}(\mathrm{OH})_{2}\right)$ & \\
\hline & $\mathrm{HDS}_{\mathrm{Ca}(\mathrm{OH})_{2}} 3$ & HDS (Coarse textured)-approximately $98 \%$ Gypsum & \\
\hline
\end{tabular}

1,2 Limestones Sites 1 and 2 are HDS Plants/Processes that use limestone alone to treat AMD.

\subsubsection{Generation of HDS by Limestone Sites 1 and 2}

This discussion is meant to facilitate understanding of the source and characteristics of the sludges from Limestone Sites 1 and 2 (Table 1). The process generating HDS from two similar plants using $\mathrm{CaCO}_{3}$ treatment alone involves a single stage process. The process begins with mixing hydrated $\mathrm{CaCO}_{3}$ in a separate mixing tank/compartment with a portion of the recycled sludge from the clarifier or solids/liquid separation compartment. The mixture is then transferred into the neutralization and oxidation reactor where AMD is introduced. The solution is rapidly mixed to encourage oxidation of metals, raising the $\mathrm{pH}$ to $>5$. This $\mathrm{pH}$ facilitates precipitation of $\mathrm{CaSO}_{4} \cdot 2 \mathrm{H}_{2} \mathrm{O}$, iron oxides and various other metal oxides and hydroxides. From the reactor, the solution flows into the clarifier where solid/water separation is facilitated by addition of flocculants. Part of the sludge (designated as $\mathrm{HDS}_{\mathrm{CaCO}_{3}}$ ) produced is recycled back to the mixing tank/chamber and the remainder is transferred to a storage facility $[4,14,17]$.

\subsubsection{Generation of HDS by Limestone Plus Lime Process}

The generation of the different sludges from the plant/site using $\mathrm{CaCO}_{3}$ plus $\mathrm{Ca}(\mathrm{OH})_{2}$ begins with the introduction of acid water emanating from coal mines and the process consists of three stages. Stage 1 involves neutralization of $A M D$ with $\mathrm{CaCO}_{3}$ and $\mathrm{Ca}(\mathrm{OH})_{2}$ in a reactor, during this processes the $\mathrm{pH}$ is increased to about 9.5 while aerated. This $\mathrm{pH}$ facilitates the precipitation of $\mathrm{CaSO}_{4} \cdot 2 \mathrm{H}_{2} \mathrm{O}$ and that of $\mathrm{Fe}$ and $\mathrm{Mn}$ as oxides. The solution overflows at the end of the reactors into clarifiers for solid/liquid separation; the clarified water feeds to green sand filters for further removal of solids. Part of the sludge generated (designated as $\mathrm{HDS}_{\mathrm{Ca}(\mathrm{OH})_{2}} 1$ ) from the clarifier is recycled back to the reactors to enhance densification of the sludge and the other portion is transferred into storage tanks. From the filters the solution passes through self-cleaning strainers to remove coarse and finer particles, the solution is then passed through ultra-filtration membranes (reverse osmosis pretreatment) to a storage tank. From this point the solution is pumped through reverse osmosis membranes, where desalinization occurs producing a permeate and reject water of low total dissolved solids (TDS $<200 \mathrm{mg} \mathrm{L}^{-1}$ ). The permeate is transferred to limestone saturators to raise $\mathrm{pH}$ of the water and the reject water proceeds to Stages 2 and 3 underflows [28,29].

Stages 2 and 3 underflow treatment involves neutralization of rejected solution with $\mathrm{Ca}(\mathrm{OH})_{2}$ in reactor where the $\mathrm{pH}$ is raising to 10.5 , encouraging the precipitation of $\mathrm{CaSO}_{4} \cdot 2 \mathrm{H}_{2} \mathrm{O}$ and magnesium hydroxide $\left(\mathrm{Mg}(\mathrm{OH})_{2}\right)$. The solution is then pumped through hydro-cyclones that separate solids into fine and coarse particles. The coarse fraction contains approximately $98 \%$ pure gypsum (designated as $\mathrm{HDS}_{\mathrm{Ca}(\mathrm{OH})_{2}} 3$ ). Part of this material is recycled back to the reactor and the other portion is transferred into a gypsum pond. From the reactor the solution overflows into the clarifier and then follows the same steps as in Stage 1, the reject water proceeds to stages 2 and 3 fines [28,29].

Stages 2 and 3 fines treatment; this is the same treatment where the coarse fraction (underflow) is produced. The fines are produced when the solution is pumped through hydro-cyclones separating them from coarse particles. The separated fine fraction contains approximately $90 \% \mathrm{CaSO}_{4} \cdot 2 \mathrm{H}_{2} \mathrm{O}$ and $10 \% \mathrm{Mg}(\mathrm{OH})_{2}$ (designated as $\left.\mathrm{HDS}_{\mathrm{Ca}(\mathrm{OH})_{2}} 2\right)$. Part of this material is recycled back into the reactor and 
the other portion is transferred into a storage facility. From the clarifier the solution follows the same steps as in stage 1, part of the rejected water is transferred back to reactors and the other portion to brine pond $[28,29]$.

It is important to note that the focus of HDS plants is on the quality of water discharged into the various river catchments and not on ensuring that the HDS produced is of a particular quality. There are no plant specific or international criteria followed to ensure quality of generated sludge.

In light of the focus on the quality of water discharged, HDS plants use natural mined limestone from nearby sedimentary sources and avoid using alkaline industrial byproducts as limestone or lime substitutes.

\subsection{HDS Sample Collection from Limestone-Site 1 Plant}

Samples were sourced in May 2016 from this site that neutralizes AMD using $\mathrm{CaCO}_{3}$ [14]. Three representative HDS samples were collected directly from the disposal pipe into the storage facility.

\subsection{Total Elemental Analyses of HDS from Limestone-Site 1 Using X-ray Fluorescence (XRF)}

Total elemental content was determined using ARL 9400XP+ Wavelength Dispersive XRF Spectrometer (Manufactured by XOS ${ }^{\mathrm{R}}$, New York, NY, USA) as described by Loubser and Verryn [30].

\subsection{Solubility Assessment of HDS from Limestone-Site 1 Using the USA EPA TCLP-1311 Procedure}

The Toxicity Characteristic Leaching Procedure (TCLP 1311): from the Solid Waste Manual 846 (SW-846), used by the US Environmental Protection Agency (EPA) [31] to assess the solubility of elements in solid wastes, was used in this study.

\subsection{Regulatory Guidelines Used to Assess HDS}

The various hazardous waste classification systems were the "instruments" in this study, it was deemed appropriate to briefly describe them under this section. This is a brief overview of the basic principles various systems are based on. In the results and discussion section the criteria are then used to classify sludges considered. The systems used can be separated into two groups: (1) systems using soluble and totals and (2) systems only using soluble.

\subsubsection{Systems Using Total and Soluble Concentrations to Classify Wastes}

Republic of South Africa (RSA) Guidelines

The RSA guidelines consider 20 constituents, with 6 of them (Mn, $\mathrm{Sb}, \mathrm{V}, \mathrm{Cl}, \mathrm{SO}_{4}, \mathrm{NO}_{3}$ ) appearing only in this system [32-34]. The guidelines compare TCLP analysis of the material against what is called Leachable Concentration Thresholds (LCTs) (Table 2, summarized in Figure 1). These thresholds are divided into LCT0 (minimum threshold), LCT1, LCT2, and LCT3 (the maximum threshold). According to the National Environmental Management: Waste Act No. 59 [32] and Costley [33], the LCT1 values were derived from the minimum values (LCT0) of the Standards for Human Health Effects for Drinking Water in RSA, by multiplying them by 50 (a generic Dilution Attenuation Factor (DAF)). This factor was suggested by the "Industrial Waste Resource Guidelines: Solid Industrial Waste Hazard Categorization and Management" of June 2009. The LCT2 values were derived by doubling the LCT1 values, while the maximum threshold (LCT3) values were derived by multiplying the LCT2 values with a factor of 4 to raise the thresholds, and this factor is also used by Environment Protection Authority (EPA) Australia, Victoria State, to calculate some of the thresholds from drinking water values. 
Table 2. Classification of waste according to the Republic of South Africa (RSA) system [32-34].

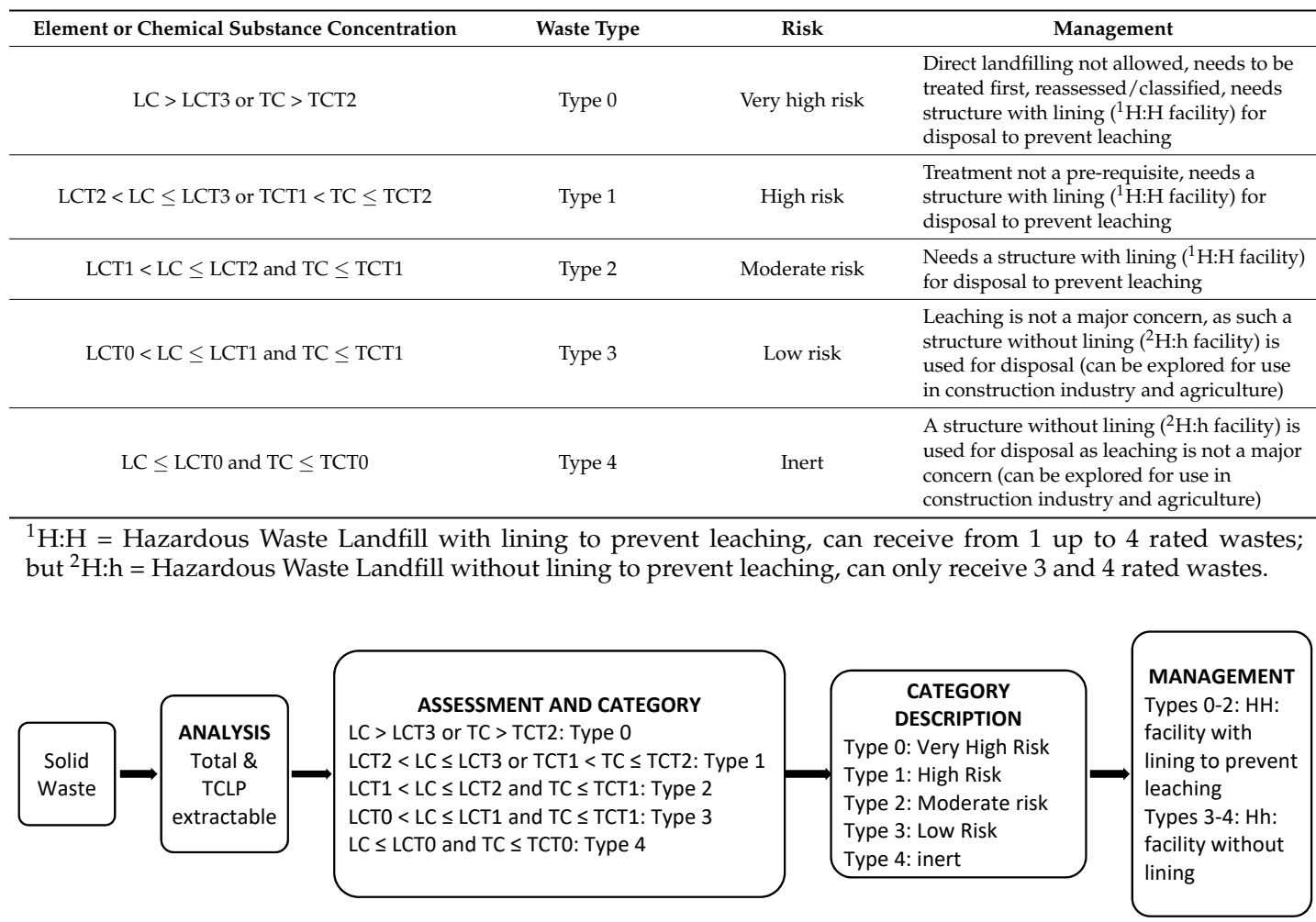

Figure 1. Simplified solid waste classification system of the Republic of South Africa (RSA).

The regulation further compares total elemental analysis of the material against stipulated Total Concentration Thresholds (TCTs). The TC thresholds are divided into TCT0 (minimum threshold), TCT1, and TCT2 (maximum threshold). The TCT0 values were obtained from RSA Soil Screening Values that are protective of water resources, while TCT1 values were derived from the Land Remediation Values for Commercial/Industrial Land determined by the Department of Environmental Affairs' "Framework for the Management of Contaminated Land", of March 2010. TCT2 values were derived by multiplying TCT1 with a factor of $4[32,33]$. After the total and soluble data of the waste have been compared to the various TCT and LCT levels, the waste is classified as outlined in Table 2.

\section{Australian (New South Wales) Guidelines}

The New South Wales (NSW) guidelines were considered as they are partially aligned to the National Waste Classification system that forms part of the Australian Waste Database (AWD). These guidelines consider a total of 9 (Table 3) elements [35]. Some of these elements (F, Mo, and Ni) were sourced from the Australian Drinking Water Guidelines [36,37], but $\mathrm{As}, \mathrm{Cd}, \mathrm{Cr}(\mathrm{VI}), \mathrm{Pb}$, and Ag were adapted from USEPA 2012b. The threshold for Be was calculated based on Be in The Health Risk Assessment and Management of Contaminated Sites. Waste is initially screened (1st screening stage) by considering total content only (referred to as Specific Contaminant Concentrations (SCC)) (Figure 2). In the case of General Solid Waste, i.e., putrescible (liable to decay), non-putrescible (equivalent to Types 3 and 4 of the South African system) the TC $\leq$ Minimum Specific Contaminant Concentrations (SCC1) Restricted Solid Waste (TC $\leq$ Maximum Specific Contaminant Concentrations (SCC2)) refers to waste that have the potential to pollute the environment (equivalent to Types 1 and 2 of the RSA system). If the TC of a constituent exceeds SCC1, further assessment with TCLP may be carried out, and if TC are equal or exceeds SCC2 thresholds, then TCLP assessment (2nd screening stage) must be done. At the second screening, using both SCC and TCLP thresholds, final clarity on the status of the waste is obtained, that is if TC > SCC1. At the second screening, TCLP is divided into TCLP1 (minimum threshold) and TCLP2 (maximum threshold). Hazardous solid waste is equivalent to Type 
0 of the RSA system [34]. The application of this system for HDS classification can be seen under results section.

Table 3. Summary of elements considered by each system.

\begin{tabular}{|c|c|c|c|c|c|c|c|}
\hline \multirow{2}{*}{ Constituent } & \multirow{2}{*}{ RSA } & \multirow{2}{*}{ Australia (New South Wales) } & \multicolumn{3}{|c|}{ Canada } & \multirow{2}{*}{ USEPA } & \multirow{2}{*}{ China } \\
\hline & & & Ontario \& Manitoba & British Columbia & Alberta & & \\
\hline As & $x$ & $x$ & & & & $x$ & $\mathrm{x}$ \\
\hline $\mathrm{Ag}$ & & $\mathrm{x}$ & $\mathrm{x}$ & $\mathrm{x}$ & $\mathrm{x}$ & $\mathrm{x}$ & $\mathrm{x}$ \\
\hline $\mathrm{B}$ & $\mathrm{x}$ & & $\mathrm{x}$ & $\mathrm{x}$ & $\mathrm{x}$ & & \\
\hline $\mathrm{Ba}$ & $\mathrm{x}$ & & $\mathrm{x}$ & $\mathrm{x}$ & $\mathrm{x}$ & $\mathrm{x}$ & $\mathrm{x}$ \\
\hline $\mathrm{Be}$ & & $\mathrm{x}$ & & & & & $\mathrm{x}$ \\
\hline $\mathrm{Cd}$ & $\mathrm{x}$ & $\mathrm{x}$ & $\mathrm{x}$ & $\mathrm{x}$ & $\mathrm{x}$ & $\mathrm{x}$ & $\mathrm{x}$ \\
\hline Co & $\mathrm{x}$ & & & & $x$ & & \\
\hline $\mathrm{Cr}$ & $\mathrm{x}$ & $\mathrm{x}$ & $\mathrm{x}$ & $\mathrm{x}$ & $\mathrm{x}$ & $\mathrm{x}$ & $\mathrm{x}$ \\
\hline $\mathrm{Cu}$ & $\mathrm{x}$ & & & $\mathrm{x}$ & $\mathrm{x}$ & & $\mathrm{x}$ \\
\hline $\mathrm{Fe}$ & & & & & $\mathrm{x}$ & & \\
\hline $\mathrm{Hg}$ & $\mathrm{x}$ & & $\mathrm{x}$ & $\mathrm{x}$ & $\mathrm{x}$ & $\mathrm{x}$ & $\mathrm{x}$ \\
\hline Mn & $x$ & & & & & & \\
\hline Mo & $\mathrm{x}$ & $x$ & & & & & \\
\hline $\mathrm{Ni}$ & $\mathrm{x}$ & $\mathrm{x}$ & & & $\mathrm{x}$ & & $\mathrm{x}$ \\
\hline $\mathrm{Pb}$ & $x$ & $\mathrm{x}$ & $\mathrm{x}$ & $\mathrm{x}$ & $\mathrm{x}$ & $\mathrm{x}$ & $x$ \\
\hline $\mathrm{Sb}$ & $x$ & & & & & & \\
\hline Se & $\mathrm{x}$ & & $\mathrm{x}$ & $\mathrm{x}$ & $\mathrm{x}$ & $\mathrm{x}$ & \\
\hline $\mathrm{U}$ & & & $\mathrm{x}$ & $\mathrm{x}$ & $\mathrm{x}$ & & \\
\hline $\mathrm{V}$ & $\mathrm{x}$ & & & & & & \\
\hline $\mathrm{Zn}$ & $\mathrm{x}$ & & & $\mathrm{x}$ & $\mathrm{x}$ & & $\mathrm{x}$ \\
\hline $\mathrm{Cl}$ & $\mathrm{x}$ & & & & & & \\
\hline $\mathrm{SO}_{4}$ & $x$ & & & & & & \\
\hline $\mathrm{NO}_{3}$ & $x$ & & & & & & \\
\hline $\mathrm{F}$ & $x$ & $x$ & & & & & \\
\hline Total & 20 & 9 & 9 & 11 & 14 & 8 & 11 \\
\hline
\end{tabular}

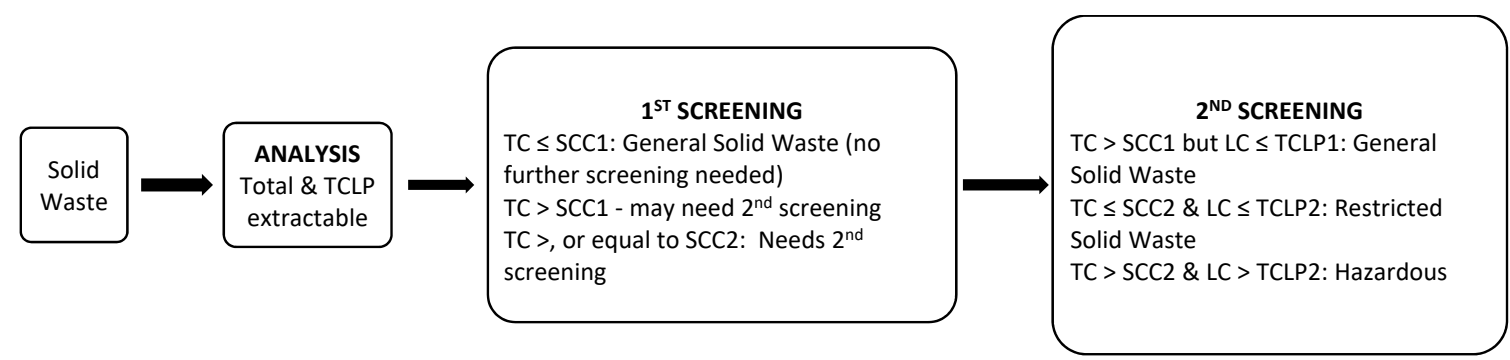

Figure 2. Simplified solid waste classification system for Australia (New South Wales).

2.5.2. Systems Using Only Soluble Concentrations of Constituents to Classify Waste

The United States of America (USEPA) Guidelines

The USEPA regulation is managed by the Resource Conservation and Recovery Act (RCRA) of 1976, and classifies wastes based on hazardous properties [38]. It considers 8 elements (Table 3) of concern [38]. These elements are considered to cause acute or chronic health effects via the groundwater route and were sourced from the National Interim Primary Drinking Water Standards (NIPDWS) [38]. The consideration of these inorganic constituents was further facilitated by available and appropriate chronic toxicity reference levels (CTRLs) on which to base the calculation of thresholds. These elements also had adequate data for the fate and transport model used to establish element specific dilution attenuation factors used to convert CTRLs to thresholds. Furthermore, these constituents have been shown to have toxic, carcinogenic, mutagenic or teratogenic effects [38]. The main concern is the solubility of these constituents, and only analysis performed is a TCLP extraction, after which the data are evaluated against threshold level (summarized in Figure 3).

The critical difference between the USEPA guidelines and the other guidelines considered, is that essential trace elements for plants/crops do not form part of their hazardous waste classification. These are $\mathrm{B}, \mathrm{Mn}, \mathrm{Fe}, \mathrm{Zn}$, and $\mathrm{Cu}$. The USEPA regulation, therefore, opens the possibility for waste materials/by products from industry and mining that have low solubilities of non-essential elements for plants and environmentally harmful constituents, to be considered for use in agriculture. 


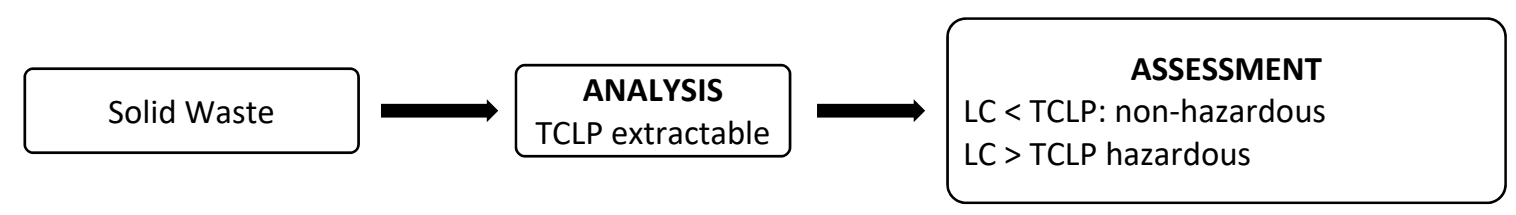

Figure 3. Simplified solid waste classification system for USEPA, China and Canada (Alberta, British Columbia, Ontario and Manitoba).

Chinese and Canadian (Alberta, British Columbia, Ontario and Manitoba) Guidelines

The Canadian and Chinese regulations also only require a TCLP extract after which the data is compared against leachability thresholds (summarized in Figure 3). China adopted the USEPA guidelines [39] except that they consider $\mathrm{Cu}, \mathrm{Ni}, \mathrm{Be}, \mathrm{Zn}$ in addition, but do not consider Se (Table 3). Thresholds for all other elements, except for $\mathrm{Hg}$, in both guidelines (China and USEPA) are identical. The Canadian guidelines are also similar to those of the USEPA, except that in addition, Alberta considers B, Co, Cu, Ni, Fe, U, Zn; British Columbia considers B, Cu, U, Zn, while Ontario and Manitoba consider $B$ and U. The USEPA guidelines consider as that the guidelines in Canada exclude.

In summary, the RSA system considers the most elements (20) and the most stringent. Both the total elemental content (referred to as "Total Concentration" determined by XRF) and the solubilities of the elements are assessed (refer to as "Leachable Concentration"). Four hazardous categories have been established (Types 0-4). Currently all waste, including type 4 (inert waste), must go to a managed storage facility. The Australia system has two screening levels. The first uses only total elemental content (referred to as "Specific Contaminant Concentration, or SCC" divided into SCC1 and SCC2 determined by XRF. If the total elemental content of a waste exceeds SCC1 thresholds, further assessment against TCLP thresholds (2nd screening stage) may be carried out, but, if the total concentration exceeds SCC2 thresholds, then TCLP assessment must be done. A material can therefore be classified as either a General, Restricted or Hazardous Solid Waste. With USEPA, Canada, and China guidelines the main concern is solubility of constituents in a waste, and as such, the approach adopted considers leachable concentration data for the waste that are evaluated against TCLP thresholds. The elements considered by the various systems are summarized below (Table 3).

\section{Results}

\subsection{HDS Elemental Content and Solubility}

Manganese was the most abundant of all metals considered by the RSA guidelines (on both a mass and molar basis) (Table 4). This was expected based on the natural abundance of elements in geology and soil in this province. After $\mathrm{Fe}, \mathrm{Mn}$ is the most abundant transition metal, and AMD dissolves and mobilises it as it percolates through geological formations and soil. The Limestone/Lime Site HDS was particularly rich in total Mn, but with low Mn solubility compared to Limestone-Sites 1 and 2 HDS. The Mn content varied across the HDS products considered and seemed to be an AMD treatment signature. An HDS process without lime treatment generates HDS with appreciable soluble $\mathrm{Mn}$ (TCLP extractable Mn). Examples of this are $\mathrm{HDS}_{\mathrm{CaCO}_{3}}$ and $\mathrm{HDS}_{\mathrm{CaCO}_{3}} 1$ sludges with soluble Mn highlighted in grey. The mechanism for immobilisation is rapid oxidation of $\mathrm{Mn}^{2+}$ to $\mathrm{Mn}^{4+}$ and subsequent precipitation of sparingly soluble $\mathrm{Mn}$ (IV) oxides under high $\mathrm{pH}$ (9-9.5) conditions [40]. The kinetics of oxidation is appreciably slower at the $\mathrm{pH}$ or alkalinity levels created by limestone, and results in incomplete oxidation of $\mathrm{Fe}^{2+}$ and $\mathrm{Mn}^{2+}$. Due to the specific interaction of $\mathrm{Mn}^{2+}$ and $\mathrm{Fe}^{2+}$ with carbonates, there is also the risk that these metals will temporarily precipitate with carbonates, most likely as surface precipitates on limestone particles, which will further decrease their propensity to be oxidized. X-ray diffraction (XRD) analysis (data not shown) for $\mathrm{HDS}_{\mathrm{CaCO}_{3}}$, detected ankerite, $\mathrm{Ca}(\mathrm{Mg}, \mathrm{Fe}, \mathrm{Mn})\left(\mathrm{CO}_{3}\right)_{2}$, confirming the presence of ferrous iron and $\mathrm{Mn}(\mathrm{II})$, as well as incomplete oxidation of the Fe and $\mathrm{Mn}$ in the HDS products. 


\subsection{Assessment of HDS Using the RSA Guidelines}

The assessment with RSA was achieved by comparing HDS data (on the right) to the thresholds (on the left) in Table 5. For the sludge $\mathrm{HDS}_{\mathrm{CaCO}_{3}}$, from Limestone-Site 1, the only element not classified as Type 3 or 4, was Mn (Table 6). The TCLP extractable Mn of $259 \mathrm{mg} \mathrm{L}^{-1}$ (highlighted in grey) in Table 5 exceeded LCT3 $\left(200 \mathrm{mg} \mathrm{L}^{-1}\right)$ resulting in a Type 0 (Table 6) being allocated to this sludge, requiring treatment and reassessment according to RSA regulations before disposal in a lined facility. As discussed earlier, the high Mn solubility was attributed to the fact that the Limestone-Site 1 process only uses limestone. The higher total $\mathrm{Mn}$ for $\mathrm{HDS}_{\mathrm{CaCO}_{3}}$ sludge can be attributed to various factors, for example, (1) the Mn concentration of the AMD may have been higher as a result of a general increasing trend or seasonal changes in mine water quality; (2) the limestone source used in the HDS process at the time of sampling. The Ni content of $\mathrm{HDS}_{\mathrm{CaCO}_{3}}$ was more in-line with the $\mathrm{HDS}_{\mathrm{Ca}(\mathrm{OH})_{2}} 1$ and can either be related to temporal changes in AMD or quality of limestone used [13]. A more detailed discussion of this is beyond the scope of this study. A consistent and characteristic signature of the $\mathrm{HDS}_{\mathrm{CaCO}_{3}}$ was $\mathrm{Ba}$, as $\mathrm{HDS}_{\mathrm{Ca}(\mathrm{OH})_{2}} 1$ exhibited low levels of this element. This could also have been a limestone signature.

The sludge, $\mathrm{HDS}_{\mathrm{Ca}(\mathrm{OH})_{2}} 1$ from Limestone/Lime process had higher $\mathrm{Co}, \mathrm{Mn}, \mathrm{Pb}, \mathrm{Ni}$, and $\mathrm{Zn}$ content than $\mathrm{HDS}_{\mathrm{CaCO}_{3}}$ sludge and all these metals exceeded the TCT0 thresholds. For this sludge, $\mathrm{HDS}_{\mathrm{Ca}(\mathrm{OH})_{2}} 1$, it seemed that $\mathrm{Pb}$ persists and is not effectively removed by the neutralization process. For both $\mathrm{HDS}_{\mathrm{Ca}(\mathrm{OH})_{2}} 2$ and $\mathrm{HDS}_{\mathrm{Ca}(\mathrm{OH})_{2}} 3$ sludges, $\mathrm{Pb}$ content exceeded the TCT0 threshold of $20 \mathrm{mg}$ $\mathrm{kg}^{-1}$ (Table 5). The RSA guidelines have set low minimum TCLP values (LCT0), especially for As, $\mathrm{Cd}, \mathrm{Pb}, \mathrm{Hg}$, and $\mathrm{Se}$. Due to detection limit difficulties, this has resulted in inconclusive results and technically also an incomplete classification (Table 6) of the Limestone-Site 1, Limestone/Lime Site HDS for some of more important elements from an environmental point of view. A TCLP extract (or any other extract) from soil or solid waste at fairly low solution to solid ratios (20:1) creates a substantially more saline and a complex matrix. As a result, method detection limits (MDLs) are always higher (often an order of a magnitude) for extracts than for drinking water. The MDL is the lowest concentration of an element in a specific extractant/matrix where its signal is statistically separable from background "noise". As, $\mathrm{Cd}, \mathrm{Pb}, \mathrm{Hg}$, and Se are especially prone to matrix and spectral interferences resulting in, for example, false positive interferences. In order to measure LCT0 concentrations repeatedly with high confidence, the TCLP MDLs for these elements should be below LCT0 concentrations.

The only total analyses given for Limestone-Site 2 were for $\mathrm{Cr}, \mathrm{Mn}, \mathrm{Zn}$, and the TCLP analyses reported were also limited for both $\mathrm{HDS}_{\mathrm{CaCO}_{3} 1} 1$ and $\mathrm{HDS}_{\mathrm{CaCO}_{3}} 2$ sludges. The Limestone-Site $2 \mathrm{HDS}$ classification was therefore largely incomplete. However, some general trends were evident. Similar to $\mathrm{HDS}_{\mathrm{CaCO}_{3}}$, soluble Mn (Table 5) was the element condemning the $\mathrm{HDS}_{\mathrm{CaCO}_{3}} 1$ in a lined pond to Type 0 (Table 6). However, the main difference between the two sludges was the higher soluble Ni in $\mathrm{HDS}_{\mathrm{CaCO}_{3}} 1$ compared to that of $\mathrm{HDS}_{\mathrm{CaCO}_{3}}$. Maree et al. [9] reported TCLP extractable Mn (211 mg $\left.\mathrm{L}^{-1}\right)$ in $\mathrm{HDS}_{\mathrm{CaCO}_{3}} 1$ sludge that exceeded LCT3 $\left(200 \mathrm{mg} \mathrm{L}^{-1}\right)$ and Ni exceeded its LCT2 threshold (7 $\left.\mathrm{mg} \mathrm{L}^{-1}\right)$.

Lead in general shows higher MDLs in TCLP and other extracts. Kavouras et al. [41] reported $0.3 \mathrm{mg} \mathrm{L}^{-1}$ ( $\mathrm{Pb}$ determined by atomic absorption spectroscopy using a graphite furnace), the Laboratory analysis of the Limestone/Lime Site, reported $0.1 \mathrm{mg} \mathrm{L}^{-1}$, while Lin and Chang [42] reported $0.016 \mathrm{mg} \mathrm{L}^{-1}$ for $\mathrm{Pb}$ in TCLP. Apart from the latter article, all the other detection limits in TCLP were an order of a magnitude higher than the LCT0 for Pb. It is believed that a more extensive investigation on TCLP MDLs for commercial laboratories for these elements will confirm the trend that LCT0 levels for some or all these elements are below typical TCLP MDLs and are therefore of no meaning and should be revised. 
Table 4. HDS data, from own characterization, literature $[17,18]$.

\begin{tabular}{|c|c|c|c|c|c|c|c|c|c|c|c|}
\hline \multirow{3}{*}{ Constituents } & \multirow{2}{*}{\multicolumn{2}{|c|}{$\frac{\text { Limestone-Site 1 }}{\mathrm{HDS}_{\mathrm{CaCO}_{3}}}$}} & \multicolumn{3}{|c|}{ Limestone-Site 2} & \multicolumn{6}{|c|}{ Limestone/Lime Site } \\
\hline & & & \multirow[b]{2}{*}{${ }^{1} \mathrm{TC}\left(\mathrm{mg} \mathrm{kg}^{-1}\right)$} & \multirow{2}{*}{$\frac{\mathrm{HDS}_{\mathrm{CaCO}_{3} 1} 1}{{ }^{2} \mathrm{TCLP}\left(\mathrm{mg} \mathrm{L}^{-1}\right)}$} & \multirow{2}{*}{$\frac{\mathrm{HDS}_{\mathrm{CaCO}_{3}{ }^{2}}}{{ }^{2} \mathrm{TCLP}\left(\mathrm{mg} \mathrm{L}^{-1}\right)}$} & \multicolumn{2}{|c|}{$\mathrm{HDS}_{\mathrm{Ca}(\mathrm{OH})_{2}} 1$} & \multicolumn{2}{|c|}{$\mathrm{HDS}_{\mathrm{Ca}(\mathrm{OH})_{2} 2}$} & \multicolumn{2}{|c|}{$\mathrm{HDS}_{\mathrm{Ca}(\mathrm{OH})_{2}} 3$} \\
\hline & ${ }^{1} \mathrm{TC}\left(\mathrm{mg} \mathrm{kg}^{-1}\right)$ & ${ }^{2} \mathrm{TCLP}\left(\mathrm{mg} \mathrm{L}^{-1}\right)$ & & & & ${ }^{1} \mathrm{TC}\left(\mathrm{mg} \mathrm{kg}^{-1}\right)$ & ${ }^{2} \mathrm{TCLP}\left(\mathrm{mg} \mathrm{L}^{-1}\right)$ & ${ }^{1} \mathrm{TC}\left(\mathrm{mg} \mathrm{kg}^{-1}\right)$ & ${ }^{2} \mathrm{TCLP}\left(\mathrm{mg} \mathrm{L}^{-1}\right)$ & ${ }^{1} \mathrm{TC}\left(\mathrm{mg} \mathrm{kg}^{-1}\right)$ & ${ }^{2} \mathrm{TCLP}\left(\mathrm{mg} \mathrm{L}^{-1}\right)$ \\
\hline As & 0.1 & $<0.01$ & N.R. & 0.2 & 0.003 & 0.5 & $<0.05$ & $<0.5$ & $<0.05$ & $<0.5$ & $<0.05$ \\
\hline $\mathrm{B}$ & & $<0.01$ & N.R. & N.R. & N.R. & 4.87 & $<0.24$ & 6.39 & $<0.24$ & 0.96 & $<0.24$ \\
\hline Ва & 465 & $<0.01$ & N.R. & N.R. & N.R. & 12 & $<0.1$ & 4 & $<0.1$ & 1 & $<0.1$ \\
\hline $\mathrm{Ca}$ & 182,961 & 626 & 40,000 & N.R. & N.R. & 180,300 & 557 & 237,000 & 559 & 224,500 & 628 \\
\hline $\mathrm{Cd}$ & $<1$ & $<0.01$ & N.R. & 0.3 & 0.01 & $<0.1$ & $<0.04$ & $<0.1$ & $<0.01$ & $<0.1$ & $<0.01$ \\
\hline Co & 73 & 2.9 & N.R. & 13 & 0.2 & 97.2 & $<0.04$ & 2.9 & $<0.04$ & 0.6 & $<0.04$ \\
\hline $\mathrm{Cu}$ & 80 & $<0.01$ & N.R. & 0.1 & 0.002 & 3 & $<0.14$ & 1 & $<0.14$ & $<1$ & $<0.14$ \\
\hline $\mathrm{Cr}$ & 68 & 0.03 & 60 & 2 & 0.03 & 2.5 & $<0.03$ & $<0.5$ & $<0.03$ & $<0.5$ & $<0.03$ \\
\hline $\mathrm{Fe}$ & 124,500 & $<0.01$ & 40,000 & 26 & 0.4 & 42,040 & $<0.4$ & 651 & $<0.4$ & 152 & $<0.4$ \\
\hline $\mathrm{Hg}$ & N.A. & N.A. & N.R. & N.R. & N.R. & $<0.1$ & $<0.02$ & $<0.1$ & $<0.01$ & $<0.1$ & $<0.02$ \\
\hline $\mathrm{K}$ & 83 & 9.9 & 200 & N.R. & N.R. & 116 & 4.8 & 68 & 10.9 & 61 & $<2.0$ \\
\hline $\mathrm{Mg}$ & 6513 & 61 & 3000 & N.R. & N.R. & $\begin{array}{l}110 \\
47,310\end{array}$ & $\begin{array}{l}4.0 \\
107\end{array}$ & $\begin{array}{c}00 \\
35,190\end{array}$ & 115 & $\begin{array}{l}2736 \\
2736\end{array}$ & 12 \\
\hline $\mathrm{Mn}$ & 7590 & 259 & 1000 & 211 & 4 & 6473 & $<0.04$ & 949 & $<0.04$ & 95 & $<0.04$ \\
\hline Mo & 3.3 & $<0.01$ & N.R. & N.R. & N.R. & $<0.1$ & $<0.04$ & 0.1 & $<0.04$ & $<0.1$ & $<0.04$ \\
\hline $\mathrm{Na}$ & 74 & $<0.04$ & 3000 & N.R. & N.R. & 612 & $<0.04$ & 588 & $<0.04$ & 279 & $<0.04$ \\
\hline $\mathrm{Ni}$ & 108 & 2.9 & N.R. & 16.5 & 0.3 & 104.9 & $<0.04$ & 2.2 & $<0.04$ & $<0.7$ & $<0.04$ \\
\hline $\mathrm{P}$ & 44 & 0.05 & N.R. & N.R. & N.R. & N.R. & $<0.1$ & N.R. & $<0.1$ & N.R. & $<0.1$ \\
\hline $\mathrm{Pb}$ & $<1$ & $<0.1$ & N.R. & N.R. & N.R. & 143 & $<0.1$ & 163 & $<0.1$ & 40 & $<0.1$ \\
\hline $\mathrm{Sb}$ & N.A. & N.A. & N.R. & N.R. & N.R. & $<1$ & $<0.04$ & $<1$ & $<0.04$ & $<1$ & $<0.04$ \\
\hline $\mathrm{Se}$ & 25 & $<0.01$ & N.R. & N.R. & N.R. & 2 & $<0.06$ & $<1$ & $<0.06$ & $<1$ & $<0.06$ \\
\hline $\mathrm{V}$ & 56 & $<0.01$ & N.R. & N.R. & N.R. & 4 & $<0.03$ & $<1$ & $<0.03$ & $<1$ & $<0.03$ \\
\hline $\mathrm{Zn}$ & 285 & 3.7 & 400 & 20.3 & 0.3 & 330 & $<0.1$ & 7 & $<0.1$ & 5 & $<0.1$ \\
\hline $\mathrm{Cl}^{-}$ & & 7 & & N.R. & N.R. & & 10.2 & & 25 & & 1.3 \\
\hline $\mathrm{SO}_{4}{ }^{2-}$ & 55,343 & 2270 & & N.R. & N.R. & & 1761 & & 1946 & & 1456 \\
\hline $\mathrm{NO}_{3}^{-}$ & & 0.1 & & N.R. & N.R. & & $<0.2$ & & 0.9 & & $<0.2$ \\
\hline $\mathrm{F}^{-}$ & & 0.8 & & N.R. & N.R. & & 1.2 & & 0.3 & & $<0.3$ \\
\hline
\end{tabular}

${ }^{1} \mathrm{TC}=$ Total Concentration; ${ }^{2} \mathrm{TCLP}=$ Toxicity Characteristic Leaching Procedure, N.A. = Not analyzed, N.R. = Not Reported 
Table 5. Waste classification of HDS using the RSA guidelines [32-34].

\begin{tabular}{|c|c|c|c|c|c|c|c|c|c|c|c|c|c|c|c|c|c|c|c|}
\hline \multirow{4}{*}{ Const. } & \multicolumn{3}{|c|}{ TC Standards $\left(\mathrm{mg} \mathrm{kg}^{-1}\right)$} & \multicolumn{4}{|c|}{ LC Standards $\left(\mathrm{mg} \mathrm{L}^{-1}\right)$} & \multicolumn{12}{|c|}{ HDS TC and LC Data Compared to Standards on the Left } \\
\hline & \multirow{3}{*}{${ }^{1}$ ТСто } & \multirow{3}{*}{${ }^{1} \mathrm{TCT} 1$} & \multirow{3}{*}{${ }^{1} \mathrm{TCT} 2$} & \multirow{3}{*}{${ }^{2} \mathrm{LCT} 0$} & \multirow{3}{*}{${ }^{2} \mathrm{LCT} 1$} & \multirow{3}{*}{${ }^{2} \mathrm{LCT} 2$} & \multirow{3}{*}{${ }^{2} \mathrm{LCT} 3$} & \multirow{2}{*}{\multicolumn{2}{|c|}{$\begin{array}{c}\text { Limestone-Site } 1 \\
\mathrm{HDS}_{\mathrm{CaCO}_{3}}\end{array}$}} & \multicolumn{4}{|c|}{ Limestone-Site 2} & \multicolumn{6}{|c|}{ Limestone/Lime Site } \\
\hline & & & & & & & & & & HDS & $\mathrm{CO}_{3} 1$ & HDS & $\mathrm{CO}_{3} 2$ & HDS & $\mathrm{OH})_{2} 1$ & HDS & $\left(\mathrm{OH}_{2} 2\right.$ & HDS $_{\text {}}$ & $(\mathrm{OH})_{2} 3$ \\
\hline & & & & & & & & $\mathrm{mg} \mathrm{L}^{-1}$ & $\mathrm{mg} \mathrm{kg}^{-1}$ & $\mathrm{mg} \mathrm{L}^{-1}$ & $\mathrm{mg} \mathrm{kg}^{-1}$ & $\mathrm{mg} \mathrm{L}^{-1}$ & $\mathrm{mg} \mathrm{kg}^{-1}$ & $\mathrm{mg} \mathrm{L}^{-1}$ & $\mathrm{mg} \mathrm{kg}^{-1}$ & $\mathrm{mg} \mathrm{L}^{-1}$ & $\mathrm{mg} \mathrm{kg}^{-1}$ & $\mathrm{mg} \mathrm{L}^{-1}$ & $\mathrm{mg} \mathrm{kg}^{-1}$ \\
\hline As & 5.8 & 500 & 2000 & 0.01 & 0.5 & 1 & 4 & $<0.01$ & 0.1 & 0.2 & N.R. & 0.003 & N.R. & $<0.05$ & 0.5 & $<0.05$ & $<0.5$ & $<0.05$ & $<0.5$ \\
\hline B & 150 & 15,000 & 60,000 & 0.5 & 25 & 50 & 200 & $<0.01$ & & N.R. & N.R. & N.R. & N.R. & $<0.24$ & 4.87 & $<0.24$ & 6.39 & $<0.24$ & 0.96 \\
\hline $\mathrm{Ba}$ & 62.5 & 6250 & 25,000 & 0.7 & 35 & 70 & 280 & $<0.01$ & 465 & N.R. & N.R. & N.R. & N.R. & $<0.1$ & 12 & $<0.1$ & 4 & $<0.1$ & 1 \\
\hline $\begin{array}{l}\mathrm{Dd} \\
\mathrm{Cd}\end{array}$ & 7.5 & 260 & 1040 & 0.003 & 0.15 & 0.3 & 1.2 & $<0.01$ & $\begin{array}{l}<1 \\
<1\end{array}$ & $\begin{array}{c}1.1 . \\
0.3\end{array}$ & N.R. & 0.01 & N.R. & $<0.04$ & $<0.1$ & $<0.01$ & $<0.1$ & $<0.01$ & $<0.1$ \\
\hline Co & 50 & 5000 & 20,000 & 0.5 & 25 & 50 & 200 & 2.9 & 73 & 13 & N.R. & 0.2 & N.R. & $<0.04$ & 97.2 & $<0.04$ & 2.9 & $<0.04$ & 0.6 \\
\hline $\mathrm{Cr}$ & 46,000 & 800,000 & N/A & 0.1 & 5 & 10 & 40 & 0.03 & 68 & 2 & 60 & 0.03 & 60 & $<0.03$ & 2.5 & $<0.03$ & $<0.5$ & $<0.03$ & $<0.5$ \\
\hline $\mathrm{Cr}(\mathrm{VI})$ & 6.5 & 500 & 2000 & 0.05 & 2.5 & 5 & 20 & & & & - & - & - & - & & & 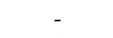 & - & 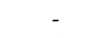 \\
\hline $\mathrm{Cu}$ & 16 & 19,500 & 78,000 & 2.0 & 100 & 200 & 800 & $<0.01$ & 80 & 0.1 & N.R. & 0.002 & N.R. & $<0.14$ & 3 & $<0.14$ & 1 & $<0.14$ & $<1$ \\
\hline $\mathrm{Hg}$ & 0.93 & 160 & 640 & 0.006 & 0.3 & 0.6 & 2.4 & N.A. & N.A. & N.R. & N.R. & N.R. & N.R. & $<0.02$ & $<0.1$ & $<0.01$ & $<0.1$ & $<0.02$ & $<0.1$ \\
\hline $\mathrm{Mn}$ & 1000 & 25,000 & 100,000 & 0.5 & 25 & 50 & 200 & 259 & 7590 & 211 & 1000 & 4 & 1000 & $<0.04$ & 6473 & $<0.04$ & 949 & $<0.04$ & 95 \\
\hline Mo & 40 & $\begin{array}{l}2,000 \\
1000\end{array}$ & 4000 & $\begin{array}{l}0.5 \\
0.07\end{array}$ & $\begin{array}{l}20 \\
3.5\end{array}$ & 7 & 28 & $<0.01$ & 3.3 & N.R. & N.R. & $\begin{array}{c}4 \\
\text { N.R. }\end{array}$ & N.R. & $<0.04$ & $\begin{array}{l}64 / 3 \\
<0.1\end{array}$ & $<0.04$ & $\begin{array}{l}949 \\
0.1\end{array}$ & $<0.04$ & $<0.1$ \\
\hline $\mathrm{Ni}$ & 91 & 10,600 & 42,400 & 0.07 & 3.5 & 7 & 28 & 2.9 & 108 & 16.5 & N.R. & 0.3 & N.R. & $<0.04$ & 104.9 & $<0.04$ & 2.2 & $<0.04$ & $<0.7$ \\
\hline $\mathrm{Pb}$ & 20 & 1900 & 7600 & 0.01 & 0.5 & 1 & 4 & $<0.1$ & $<1$ & N.R. & N.R. & N.R. & N.R. & $<0.1$ & 143 & $<0.1$ & 163 & $<0.1$ & 40 \\
\hline $\mathrm{Sb}$ & 10 & 75 & 300 & 0.02 & 1.0 & 2 & 8 & N.A. & N.A. & N.R. & N.R. & N.R. & N.R. & $<0.04$ & $<1$ & $<0.04$ & $<1$ & $<0.04$ & $<1$ \\
\hline $\mathrm{Se}$ & 10 & 50 & 200 & 0.01 & 0.5 & 1 & 4 & $<0.01$ & 25 & N.R. & N.R. & N.R. & N.R. & $<0.06$ & 2 & $<0.06$ & $<1$ & $<0.06$ & $<1$ \\
\hline V & 150 & 2680 & 10,720 & 0.2 & 10 & 20 & 80 & $<0.01$ & 56 & N.R. & N.R. & N.R. & N.R. & $<0.03$ & 4 & $<0.03$ & $<1$ & $<0.03$ & $<1$ \\
\hline $\mathrm{Zn}$ & 240 & 160,000 & 640,000 & 5.0 & 250 & 500 & 2000 & 3.7 & 285 & 20.3 & 400 & 0.3 & 400 & $<0.1$ & $\begin{array}{l}\mathbf{4} \\
330\end{array}$ & $<0.1$ & 7 & $<0.1$ & 5 \\
\hline $\mathrm{Cl}$ & & & & 300 & 15,000 & 30,000 & 120,000 & 7 & & N.R. & & N.R. & & 10.2 & & 25 & & 1.3 & \\
\hline $\mathrm{SO}_{4}$ & & & & 250 & 12,500 & 25,000 & 100,000 & 2270 & 55,343 & N.R. & & N.R. & & 1761 & & 1946 & & 1456 & \\
\hline $\mathrm{NO}_{3}$ & & & & 11 & 550 & 1100 & 4400 & 0.1 & & N.R. & & N.R. & & $<0.2$ & & 0.9 & & $<0.2$ & \\
\hline $\mathrm{F}$ & & & & 1.5 & 75 & 150 & 600 & 0.8 & & N.R. & & N.R. & & 1.2 & & 0.3 & & $<0.3$ & \\
\hline
\end{tabular}

${ }^{1} \mathrm{TCT}=$ Total concentration Threshold values and ${ }^{2} \mathrm{LCT}=$ Leachable Concentration Threshold values. 
Table 6. Classification results obtained from Table 5 using the RSA guidelines.

\begin{tabular}{|c|c|c|c|c|c|c|}
\hline \multirow[t]{2}{*}{ Constituents } & \multirow{2}{*}{$\begin{array}{c}\text { Limestone-Site } 1 \\
\mathrm{HDS}_{\mathrm{CaCO}_{3}}\end{array}$} & \multicolumn{2}{|c|}{ Limestone-Site 2} & \multicolumn{3}{|c|}{ Limestone/Lime Site } \\
\hline & & $\mathrm{HDS}_{\mathrm{CaCO}_{3}} \mathbf{1}$ & $\mathrm{HDS}_{\mathrm{CaCO}_{3}} 2$ & $\mathrm{HDS}_{\mathrm{Ca}(\mathrm{OH})_{2}} 1$ & $\mathrm{HDS}_{\mathrm{Ca}(\mathrm{OH})_{2}}{ }^{2}$ & $\mathrm{HDS}_{\mathrm{Ca}(\mathrm{OH})_{2}{ }^{3}}$ \\
\hline As & 4 & 3 & 4 & Inconcl & Inconcl & Inconcl \\
\hline B & - & - & - & 4 & 4 & 4 \\
\hline $\mathrm{Ba}$ & 3 & - & - & 4 & 4 & 4 \\
\hline $\mathrm{Cd}$ & Inconcl & Inconcl & Inconcl & Inconcl & Inconcl & Inconcl \\
\hline $\mathrm{Co}$ & 3 & 3 & 4 & 3 & 4 & 4 \\
\hline $\mathrm{Cr}$ & 4 & 3 & 4 & 4 & 4 & 4 \\
\hline $\mathrm{Cr}(\mathrm{VI})$ & - & - & - & - & - & - \\
\hline $\mathrm{Cu}$ & 3 & 4 & 4 & 4 & 4 & 4 \\
\hline $\mathrm{Hg}$ & - & - & - & Inconcl & Inconcl & Inconcl \\
\hline $\mathrm{Mn}$ & 0 & 0 & 3 & 3 & 4 & 4 \\
\hline Mo & 4 & - & - & 4 & 4 & 4 \\
\hline $\mathrm{Ni}$ & 3 & 1 & 3 & 3 & 4 & 4 \\
\hline $\mathrm{Pb}$ & Inconcl & - & - & Inconcl & Inconcl & Inconcl \\
\hline $\mathrm{Sb}$ & - & - & - & Inconcl & Inconcl & Inconcl \\
\hline Se & 3 & - & - & Inconcl & Inconcl & Inconcl \\
\hline $\mathrm{V}$ & 4 & - & - & 4 & 4 & 4 \\
\hline $\mathrm{Zn}$ & 3 & 3 & 3 & 3 & 4 & 4 \\
\hline $\mathrm{Cl}$ & 4 & - & - & 4 & 4 & 4 \\
\hline $\mathrm{SO}_{4}$ & 3 & - & - & 3 & 3 & 3 \\
\hline $\mathrm{NO}_{3}$ & 4 & - & - & 4 & 4 & 4 \\
\hline F & 4 & - & - & 4 & 4 & 4 \\
\hline Overall Type & 0 & 0 & 3 & 3 & 4 & 4 \\
\hline
\end{tabular}

Note: Inconcl = Inconclusive analysis. 


\subsection{Assessment of HDS Using Australian (New South Wales) Guidelines}

The Australian guidelines define total F, Ag, Be levels where the RSA guidelines do not. As a result, analysis of these elements is not required for hazardous waste characterisation in RSA and a judgement on these elements with the Australian system could not be made. On the 1st screening stage (Table 7) the Australian regulations indicate that $\mathrm{Ni}\left(108 \mathrm{mg} \mathrm{kg}^{-1}\right.$ highlighted in grey) for $\mathrm{HDS}_{\mathrm{CaCO}_{3}}$, from Limestone-Site 1, exceeded SCC1 $\left(40 \mathrm{mg} \mathrm{kg}^{-1}\right)$ allocating a Restricted Solid Waste status to the material, meaning it can pollute the environment. The material was then assessed against both SCC and TCLP, the 2nd Screening stage (Table 8). The elements considered for this sludge were found to be below SCC1 thresholds, but when compared against TCLP thresholds, only Ni ( $2.9 \mathrm{mg} \mathrm{L}^{-1}$ highlighted in grey) exceeded TCLP1 $\left(2.0 \mathrm{mg} \mathrm{L}^{-1}\right)$ confirming the classification of the material as a Restricted Solid Waste. This categorization is equivalent to Types 1 to 2 in the RSA system. Only Ni was highlighted as an element of concern because the Australian guidelines do not consider Mn.

The sludge, $\mathrm{HDS}_{\mathrm{CaCO}_{3}} 1$, from Limestone-Site 2 was allocated a hazardous status (equivalent to Type 0 of the RSA system) since its $\mathrm{Ni}\left(16.5 \mathrm{mg} \mathrm{L}^{-1}\right.$ highlighted in grey) exceeded TCLP2 $\left(8.0 \mathrm{mg} \mathrm{L}^{-1}\right)$ and $\mathrm{HDS}_{\mathrm{CaCO}_{3}} 2$ from the same site was categorized as a General Solid Waste, since all its TCs and LCs were below SCC1 and TCLP1 thresholds (Tables 7 and 8). The other sludges, $\mathrm{HDS}_{\mathrm{Ca}(\mathrm{OH})_{2}} 1$, from Limestone/Lime Site had TCs for Pb (143 $\mathrm{mg} \mathrm{kg}^{-1}$ highlighted in grey) and Ni (104.9 $\mathrm{mg} \mathrm{kg}^{-1}$ highlighted in grey) exceeding their thresholds (only in the 1st screening stage-Table 7), $\mathrm{HDS}_{\mathrm{Ca}(\mathrm{OH})_{2}} 2$ also had its TC for $\mathrm{Pb}\left(163 \mathrm{mg} \mathrm{kg}^{-1}\right.$ highlighted in grey) exceeding its threshold (only in the $1^{\text {st }}$ screening stage-Table 7), categorising both materials as Restricted Solid Wastes, but $\mathrm{HDS}_{\mathrm{Ca}(\mathrm{OH})_{2}} 3$ from the same site was categorized as a General Solid Waste (allowing exploration for use by either construction industry or agriculture).

\subsection{Assessment of HDS Based on Canadian, US, and Chinese Guidelines}

Guidelines for these countries rely only on TCLP data (Table 9). To achieve the assessment, the TCLP extracted data presented on the right of Table 9 were compared to the thresholds presented on the left portion of the same Table. When comparing $\mathrm{HDS}_{\mathrm{CaCO}_{3}}$ sludge to the USEPA, Canadian, and Chinese guidelines, all of the LC values considered were below threshold levels, categorizing this material as non-hazardous waste. This suggested that no restrictions are needed for the disposal of this sludge and the potential for its use in agriculture or construction industry can be explored.

$\mathrm{HDS}_{\mathrm{CaCO}_{3}} 1$ from Limestone-Site 2 had an LC for $\mathrm{Ni}\left(16.5 \mathrm{mg} \mathrm{L}^{-1}\right.$ highlighted in grey) exceeding Canada's (Alberta) and China's TCLP threshold (of $5 \mathrm{mg} \mathrm{L}^{-1}$ ) thereby classifying the material as hazardous waste. The other three systems classified this sludge as non-hazardous. The source of the acid waters treated in the Limestone-Site 2 has not been confirmed as being solely of coal mining origin, and it should be noted that a major metalliferous processing organisation is situated upstream of the Limestone-Site 2 treatment plant. Analyses for $\mathrm{HDS}_{\mathrm{CaCO}_{3}} 2$ were below TCLP thresholds for all countries, assigning the material a non-hazardous status. When evaluating sludges from Limestone/Lime Site $\left(\mathrm{HDS}_{\mathrm{Ca}(\mathrm{OH})_{2}} 1, \mathrm{HDS}_{\mathrm{Ca}(\mathrm{OH})_{2}} 2 \mathrm{HDS}_{\mathrm{Ca}(\mathrm{OH})_{2}} 3\right)$ against the USEPA, Canadian, and Chinese guidelines, none of the LCs exceeded TCLP thresholds of any of the guidelines.

\subsection{Comparison of Assessments Using the US, Australian, Canadian, and Chinese Classifications with the South African System}

In summary (Table 10), the USEPA classification allocated a non-hazardous status to all six HDS assessed. Accordingly, all these sludges would be open for exploration for use in the construction industry or agriculture. Two elements, $\mathrm{Mn}$ and $\mathrm{Ni}$, resulted in Type 0 or Type 1 categorisation by the RSA system for two of the sludges from the limestone treatment plants. With Australia, $\mathrm{Ni}$ and $\mathrm{Pb}$ remained the main soluble elements that allocated either a Restricted Solid Waste or hazardous status to some of the sludges. Soluble $\mathrm{Ni}$ was the only element that allocated a hazardous status to one of the sludges from the limestone treatment plants with Canadian (Alberta) and Chinese guidelines. 
Table 7. Waste classification without TCLP data (1st Screening stage) [35].

\begin{tabular}{|c|c|c|c|c|c|c|c|}
\hline \multirow{3}{*}{ Element } & \multicolumn{2}{|c|}{ Standards $\left(\mathrm{mg} \mathrm{kg}^{-1}\right)$} & \multicolumn{5}{|c|}{ HDS TC Data ( $\mathrm{mg} \mathrm{kg}^{-1}$ ) Compared to Standards on the Left } \\
\hline & \multirow{2}{*}{${ }^{1} \mathrm{SCC} 1\left(\mathrm{mg} \mathrm{kg}^{-1}\right)$} & \multirow{2}{*}{${ }^{1} \mathrm{SCC} 2\left(\mathrm{mg} \mathrm{kg}^{-1}\right)$} & \multirow{2}{*}{$\frac{\text { Limestone-Site } 1}{\mathrm{HDS}_{\mathrm{CaCO}_{3}}}$} & \multirow{2}{*}{$\begin{array}{c}\text { Limestone-Site } 2 \\
\mathrm{HDS}_{\mathrm{CaCO}_{3} 1 \& \mathrm{HDS}_{\mathrm{CaCO}_{3} 2} 2}\end{array}$} & \multicolumn{3}{|c|}{$\begin{array}{l}\text { Limestone/Lime Site } \\
\end{array}$} \\
\hline & & & & & $\mathrm{HDS}_{\mathrm{Ca}(\mathrm{OH})_{2}} 1$ & $\mathrm{HDS}_{\mathrm{Ca}(\mathrm{OH})_{2} 2} 2$ & $\mathrm{HDS}_{\mathrm{Ca}(\mathrm{OH})_{2} 3} 3$ \\
\hline $\mathrm{Ag}$ & 100 & 400 & & - & & & \\
\hline As & 100 & 400 & 0.1 & - & 0.5 & $<0.5$ & $<0.5$ \\
\hline Be & 20 & 80 & - & - & & & \\
\hline $\mathrm{Cd}$ & 20 & 80 & $<1$ & - & $<0.1$ & $<0.1$ & $<0.1$ \\
\hline $\mathrm{Cr}$ & 100 & 400 & 68 & 60 & 2.5 & $<0.5$ & $<0.5$ \\
\hline $\mathrm{F}$ & 3000 & 12,000 & - & - & & & \\
\hline $\mathrm{Pb}$ & 100 & 400 & $<1$ & - & 143 & 163 & 40 \\
\hline $\mathrm{Hg}$ & 4 & 16 & NA & - & $<0.1$ & $<0.1$ & $<0.1$ \\
\hline Mo & 100 & 400 & 3.3 & - & $<0.1$ & 0.1 & $<0.1$ \\
\hline $\mathrm{Ni}$ & 40 & 160 & 108 & - & 104.9 & 2.2 & $<0.7$ \\
\hline $\mathrm{Se}$ & 20 & 80 & 25 & - & 2 & $<1$ & $<1$ \\
\hline $\begin{array}{c}\text { Overall } \\
\text { classification }\end{array}$ & & & RSW & GSW & RSW & RSW & GSW \\
\hline
\end{tabular}

${ }^{1}$ SCC $=$ Specific Contaminant Concentrations, N.A. = Not analyzed, RSW = Restricted Solid Waste and GSW = General Solid Waste. Note: If TC $\leq$ SCC1: General Solid Waste (no further screening needed), TC > SCC1: may need 2nd screening, TC $\geq$ SCC2: Restricted Solid Waste (needs 2nd screening).

Table 8. Assessment of sludge hazardous status based on both TCLP and SCC thresholds (2nd Screening stage) [35].

\begin{tabular}{|c|c|c|c|c|c|c|c|c|c|c|c|c|c|c|c|c|}
\hline \multirow{4}{*}{ Element } & \multicolumn{4}{|c|}{ Standards } & \multicolumn{12}{|c|}{ HDS TCLP Extracted and TC Data Compared to the Standards on the Left } \\
\hline & \multirow{3}{*}{$\begin{array}{l}{ }^{2} \mathrm{TCLP1} \\
\mathrm{mg} \mathrm{L}^{-1}\end{array}$} & \multirow{3}{*}{$\begin{array}{c}{ }^{1} \mathrm{SCC} 1 \\
\mathrm{mg} \mathrm{kg}^{-1}\end{array}$} & \multirow{3}{*}{$\begin{array}{l}{ }^{2} \text { TCLP2 } \\
\mathrm{mg} \mathrm{L}^{-1}\end{array}$} & \multirow{3}{*}{$\begin{array}{c}{ }^{1} \mathrm{SCC} 2 \\
\mathrm{mg} \mathrm{kg}^{-1}\end{array}$} & \multirow{2}{*}{\multicolumn{2}{|c|}{$\begin{array}{c}\text { Limestone-Site } 1 \\
\mathrm{HDS}_{\mathrm{CaCO}_{3}}\end{array}$}} & \multicolumn{4}{|c|}{ Limestone-Site 2} & \multicolumn{6}{|c|}{ Limestone/Lime Site } \\
\hline & & & & & & & \multicolumn{2}{|c|}{$\mathrm{HDS}_{\mathrm{CaCO}_{3} 1}$} & \multicolumn{2}{|c|}{$\mathrm{HDS}_{\mathrm{CaCO}_{3}{ }^{2}}$} & \multicolumn{2}{|c|}{$\mathrm{HDS}_{\mathrm{Ca}(\mathrm{OH})_{2}} 1$} & \multicolumn{2}{|c|}{$\mathrm{HDS}_{\mathrm{Ca}(\mathrm{OH})_{2}}{ }^{2}$} & \multicolumn{2}{|c|}{$\mathrm{HDS}_{\mathrm{Ca}(\mathrm{OH})_{2}} 3$} \\
\hline & & & & & $\mathrm{mg} \mathrm{L}^{-1}$ & $\mathrm{mg} \mathrm{kg}^{-1}$ & $\mathrm{mg} \mathrm{L}^{-1}$ & $\mathrm{mg} \mathrm{kg}^{-1}$ & $\mathrm{mg} \mathrm{L}^{-1}$ & $\mathrm{mg} \mathrm{kg}^{-1}$ & $\mathrm{mg} \mathrm{L}^{-1}$ & $\mathrm{mg} \mathrm{kg}^{-1}$ & \multicolumn{2}{|c|}{$\mathrm{mg} \mathrm{L}^{-1} \quad \mathrm{mg} \mathrm{kg}^{-1}$} & \multicolumn{2}{|c|}{$\frac{\mathrm{HDS}_{\mathrm{Ca}(\mathrm{OH})_{2}}{ }^{3}}{\mathrm{mg} \mathrm{I}^{-1}}$} \\
\hline $\mathrm{Ag}$ & 5.0 & 180 & 20 & 270 & - & - & - & - & - & - & - & - & - & - & - & - \\
\hline $\mathrm{Be}$ & 1.0 & 100 & 4 & 400 & - & - & - & - & - & - & - & - & - & - & - & - \\
\hline $\mathrm{Cd}$ & 1.0 & 100 & 4 & 400 & $<0.01$ & $<1$ & 0.3 & - & 0.01 & - & $<0.01$ & $<0.1$ & $<0.01$ & $<0.1$ & $<0.01$ & $<0.1$ \\
\hline $\mathrm{Cr}$ & 5.0 & 1900 & 20 & 7600 & 0.03 & 68 & 2 & 60 & 0.03 & 60 & $<0.03$ & 2.5 & $<0.03$ & $<0.5$ & $<0.03$ & $<0.5$ \\
\hline $\mathrm{F}$ & 2.0 & 75 & 8 & 300 & 0.8 & - & - & - & - & - & 1.2 & - & 0.3 & - & $<0.3$ & - \\
\hline $\mathrm{Pb}$ & 5.0 & 1500 & 20 & 6000 & $<0.1$ & $<1$ & - & - & - & - & $<0.1$ & 143 & $<0.1$ & 163 & $<0.1$ & 40 \\
\hline $\mathrm{Hg}$ & 0.2 & 50 & 0.8 & 200 & N.A. & N.A. & - & - & - & - & $<0.02$ & $<0.1$ & $<0.01$ & $<0.1$ & $<0.02$ & $<0.1$ \\
\hline $\mathrm{Ni}$ & 2.0 & 1050 & 8 & 4200 & 2.9 & 108 & 16.5 & - & 0.3 & - & $<0.04$ & 104.9 & $<0.04$ & 2.2 & $<0.04$ & $<0.7$ \\
\hline Se & 1.0 & 50 & 4 & 200 & $<0.01$ & 25 & - & - & - & - & $<0.06$ & 2 & $<0.06$ & $<1$ & $<0.06$ & $<1$ \\
\hline Overall Classif & & & & & \multicolumn{2}{|c|}{ RSW } & \multicolumn{2}{|c|}{ HW } & \multicolumn{2}{|c|}{ GSW } & \multicolumn{2}{|c|}{ RSW } & \multicolumn{2}{|c|}{ RSW } & \multicolumn{2}{|c|}{ GSW } \\
\hline
\end{tabular}

${ }^{1} \mathrm{SCC}=$ Specific Contaminant Concentrations,${ }^{2}$ TCLP $=$ Toxicity Characteristic Leaching Procedure, N.A. = Not analyzed, RSW = Restricted Solid Waste and GSW $=$ General Solid Waste

Note: If TC > SCC1 but LC $\leq$ TCLP1: General Solid Waste, TC $\leq$ SCC2 \& LC $\leq$ TCLP2: Restricted Solid Waste, TC > SCC2 \& LC > TCLP2: Hazardous. 
Table 9. Assessment of HDS based on leachable concentrations (LC) using regulatory guidelines for Canada, USEPA and China [3,38].

\begin{tabular}{|c|c|c|c|c|c|c|c|c|c|c|c|}
\hline \multirow{3}{*}{ Constituents } & \multicolumn{5}{|c|}{ Standards $\left(\mathrm{mg} \mathrm{L}^{-1}\right)$} & \multicolumn{6}{|c|}{ HDS TCLP Extracted Data ( $\mathrm{mg} \mathrm{L}^{-1}$ ) Compared to Standards on the Left } \\
\hline & \multicolumn{3}{|c|}{ Canada } & \multirow{2}{*}{ USEPA } & \multirow{2}{*}{ China } & \multirow{2}{*}{$\begin{array}{c}\text { Limestone-Site } 1 \\
\mathrm{HDS}_{\mathrm{CaCO}_{3}}\end{array}$} & \multicolumn{2}{|c|}{ Limestone-Site 2} & \multicolumn{3}{|c|}{ Limestone/Lime Site } \\
\hline & Ontario \& Manitoba & British Columbia & Alberta & & & & $\mathrm{HDS}_{\mathrm{CaCO}_{3} 1} 1$ & $\mathrm{HDS}_{\mathrm{CaCO}_{3}{ }^{2}}$ & $\mathrm{HDS}_{\mathrm{Ca}(\mathrm{OH})_{2}}$ & $1 \mathrm{HDS}_{\mathrm{Ca}(\mathrm{OH})_{2}}{ }^{2}$ & $\mathrm{HDS}_{\mathrm{Ca}(\mathrm{OH})_{2}{ }^{3}}$ \\
\hline $\mathrm{Ba}$ & 100 & 100 & 100 & 100 & 100 & $<0.01$ & - & - & $<0.1$ & $<0.1$ & $<0.1$ \\
\hline B & 500 & 500 & 500 & - & - & $<0.01$ & - & - & $<0.24$ & $<0.24$ & $<0.24$ \\
\hline $\mathrm{Cd}$ & 5 & 5 & 1 & 1 & 1 & $<0.01$ & 0.3 & 0.01 & $<0.01$ & $<0.01$ & $<0.01$ \\
\hline $\mathrm{Cr}$ & 5 & 5 & 5 & 5 & 5 & 0.03 & 2 & 0.03 & $<0.03$ & $<0.03$ & $<0.03$ \\
\hline Co & - & - & 100 & - & & 2.9 & 13 & 0.2 & $<0.04$ & $<0.04$ & $<0.04$ \\
\hline $\mathrm{Cu}$ & - & 100 & 100 & - & 100 & $<0.01$ & 0.1 & 0.002 & $<0.14$ & $<0.14$ & $<0.14$ \\
\hline $\mathrm{Fe}$ & - & - & 1000 & - & - & $<0.1$ & 26 & 0.4 & $<0.4$ & $<0.4$ & $<0.4$ \\
\hline $\mathrm{Pb}$ & 5 & 5 & 5 & 5 & 5 & $<0.1$ & & - & $<0.1$ & $<0.1$ & $<0.1$ \\
\hline $\mathrm{Hg}$ & 0.1 & 0.1 & 0.2 & 0.2 & 0.1 & - & - & - & $<0.02$ & $<0.01$ & $<0.02$ \\
\hline $\mathrm{Ni}$ & - & - & 5 & - & 5 & 2.9 & 16.5 & 0.3 & $<0.04$ & $<0.04$ & $<0.04$ \\
\hline $\mathrm{Se}$ & 1 & 1 & 1 & 1 & & $<0.01$ & & - & $<0.06$ & $<0.06$ & $<0.06$ \\
\hline $\mathrm{Ag}$ & 5 & 5 & 5 & 5 & 5 & - & - & - & - & - & - \\
\hline $\mathrm{U}$ & 2 & 10 & 2 & - & - & - & - & - & - & - & - \\
\hline $\mathrm{Zn}$ & - & 500 & 500 & - & 100 & 3.7 & 20.3 & 0.3 & $<0.1$ & $<0.1$ & $<0.1$ \\
\hline As & - & - & - & 5 & 5 & $<0.01$ & 0.2 & 0.003 & $<0.05$ & $<0.05$ & $<0.05$ \\
\hline Be & - & - & - & & 0.02 & & & & - & - & \\
\hline
\end{tabular}

Note: If LC < TCLP: non-hazardous, LC > TCLP hazardous.

Table 10. Summary of elements that influenced classification of HDS by the different systems.

\begin{tabular}{|c|c|c|c|c|c|c|}
\hline \multirow{3}{*}{ Element } & \multicolumn{6}{|c|}{ High Density Sludge } \\
\hline & \multirow{2}{*}{$\begin{array}{c}\text { Limestone-Site } 1 \\
\mathrm{HDS}_{\mathrm{CaCO}_{3}}\end{array}$} & \multicolumn{2}{|c|}{ Limestone-Site 2} & \multicolumn{3}{|c|}{ Limestone/Lime Site } \\
\hline & & $\mathrm{HDS}_{\mathrm{CaCO}_{3}} \mathbf{1}$ & $\mathrm{HDS}_{\mathrm{CaCO}_{3}} 2$ & $\mathrm{HDS}_{\mathrm{Ca}(\mathrm{OH})_{2}} 1$ & $\mathrm{HDS}_{\mathrm{Ca}(\mathrm{OH})_{2}}{ }^{2}$ & $\mathrm{HDS}_{\mathrm{Ca}(\mathrm{OH})_{2}} 3$ \\
\hline $\mathrm{Mn}$ & RSA & RSA & None & None & None & None \\
\hline $\mathrm{Ni}$ & NSW & $\begin{array}{c}\text { RSA, NSW, Alberta \& } \\
\text { China }\end{array}$ & None & NSW & None & None \\
\hline $\mathrm{Pb}$ & None & None & None & NSW & NSW & None \\
\hline
\end{tabular}

Note: NSW = New South Wales; RSA = Republic of South Africa. 


\subsection{Should Mn Form Part of Hazardous Waste Classification?}

The $\mathrm{HDS}_{\mathrm{CaCO}_{3} 1} 1$ product, from Limestone-Site 2 was flagged by the majority of the guidelines (Canada, China, and Australia) based on soluble Ni (USEPA does not consider Ni). $\mathrm{HDS}_{\mathrm{CaCO}_{3}}$, from limestone-Site 1 , and $\mathrm{HDS}_{\mathrm{CaCO}_{3} 1} 1$ were both flagged on the basis of $\mathrm{Mn}$, but only by the RSA guidelines. The RSA guidelines are very thorough in the number of elements they consider, and sensibly omit Fe and Al. However, it is the only system that considers Mn. Like Fe, Mn forms sparingly soluble oxides and this is most likely the reason why most countries do not consider it to be an element of major concern. The critical aspect at HDS plants is whether lime or limestone has been used in the neutralizing process. Lime accelerates oxidation kinetics because of the higher $\mathrm{pH}$. If limestone is used, more time is needed at the lower $\mathrm{pH}$ for complete oxidation and formation of Mn (IV) oxides. Once formed, Mn (IV) oxides are exceedingly insoluble as demonstrated by the $\mathrm{HDS}_{\mathrm{Ca}(\mathrm{OH})_{2}} 1 \mathrm{HDS}$ which had almost $7000 \mathrm{mg} \mathrm{kg}^{-1}$ of $\mathrm{Mn}$, yet the solubility was below $0.04 \mathrm{mg} \mathrm{L}^{-1}$.

$\mathrm{Mn}$ is also a common soil constituent especially in a South African context. This is another environment where the low solubility of $\mathrm{Mn}$ from $\mathrm{Mn}(\mathrm{IV})$ oxides is demonstrated. The best example is the manganiferous soils derived from the Malmani dolomites in RSA which have been used for irrigation for 150 years or longer and have been critical in providing food for the large urban and peri-urban Gauteng population. These soils span important agricultural areas in Gauteng, parts of the Northwest and Mpumalanga Provinces of South Africa contain up to $13,000 \mathrm{mg} \mathrm{kg}^{-1}$ of Mn (more than double the Mn total content of the $\left.\mathrm{HDS}_{\mathrm{Ca}(\mathrm{OH})_{2}} 1\right)$ [43]. This means that these soils would be Type 1 (high risk) wastes if they were to be classified using the RSA system based on TC.

Apart from their low solubility, Mn (IV) oxides also have various other benefits. Their metal scavenging abilities are well-known and have a particularly high affinity for B-type cations (soft metals), especially $\mathrm{Pb}$ [44]. They also have the ability to oxidize organic pollutants in the soil and are more likely playing a critical role in protecting environmental quality rather than harming it. Furthermore, the oxidizing propensity it lends to environments is well-known in soil research and commonly observed in dolomite derived soils [40]. Mn(IV) oxides will not only help buffer ferric oxide reduction and dissolution but also actively oxidize (or re-oxidize) ferrous iron and $\mathrm{Mn}^{2+}$. If As occurs in the waste, the presence of $\mathrm{Mn}$ will result in its oxidation to the less soluble As(V) arsenate [45].

Based on the arguments made on the low solubility of Mn(IV) oxides and of the potential environmental benefits, it seems prudent to omit total Mn content from the South African system, as has already been done with Fe.

\section{Conclusions}

The article attempted to address a pertinent question currently asked about HDS from coalmine water neutralisation. The approach followed was to determine the hazardous waste classification of various HDS products using various global systems. One consistency between the Canadian, Chinese, Australian, and RSA systems was the classification of $\mathrm{HDS}_{\mathrm{CaCO}_{3}} 1$ sludge from limestone-Site 2 as hazardous waste. In the case of the Canadian, Chinese, and Australian systems it was because of $\mathrm{Ni}$ solubility. For the RSA system it was for both Ni and Mn solubility because it is the only system that considers Mn. Apart from this HDS, the Canadian and Chinese systems did not consider any other of the HDS assessed as hazardous. None of the sludges was considered by the USEPA guidelines as hazardous because Ni is not included in their system. The Australian system further classified three other sludges $\left(\mathrm{HDS}_{\mathrm{CaCO}_{3}}, \mathrm{HDS}_{\mathrm{Ca}(\mathrm{OH})_{2}} 1, \mathrm{HDS}_{\mathrm{Ca}(\mathrm{OH})_{2}} 2\right)$ as Restricted Solid Wastes, based on $\mathrm{Ni}$ solubility, while two $\left(\mathrm{HDS}_{\mathrm{CaCO}_{3}} 2, \mathrm{HDS}_{\mathrm{Ca}(\mathrm{OH})_{2}} 3\right)$ were classed as General Solid Wastes. One other sludge $\left(\mathrm{HDS}_{\mathrm{CaCO}_{3}}\right.$ ) was classified as highly hazardous due to Mn and Ni solubility by the RSA system and needs to be retreated before deposition in a lined facility. The remaining sludges were classed as type 3 or type 4 by the same system. The LCT0 values for several elements in TCLP extracts are below detection limits using methods available in South Africa. Consequently, incomplete classification of waste is at risk. Changing the LCT0 values for these elements to >MDL TCLP (below the Method Detection Limit in TCLP) would still be lower than the single soluble screening levels of the other 
systems. Considering all the systems, the probability for the HDS investigated to be classified as hazardous waste increases if the material is only subjected to limestone treatment. The element flagged was Ni.

Author Contributions: B.H.S., J.G.A., and P.C.D.J. participated in the conceptualization of the project. B.H.S. with the help of P.C.D.J. further designed the methodology. B.H.S. then carried out formal analysis and writing up of the original draft. J.G.A. was further responsible for required resources, supervision, project administration, and funding acquisition. P.D.T. helped in supervision reviewing and editing the paper.

Funding: This research was funded by Water Research Commission (WRC) of South Africa, Project Number K5/2564.

Acknowledgments: The authors wish to acknowledge the University of Pretoria for the resources (laboratory and technical staff) rendered making this work a reality.

Conflicts of Interest: The authors declare no conflict of interest.

\section{References}

1. Demers, I.; Mbonimpa, M.; Benzaazoua, M.; Bouda, M.; Awoh, S.; Lortie, S.; Gagnon, M. Use of acid mine drainage treatment sludge by combination with a natural soil as an oxygen barrier cover for mine waste reclamation: Laboratory column tests and intermediate scale field tests. Miner. Eng. 2017, 107, 43-52. [CrossRef]

2. Wang, L.K.; Shammas, N.K.; Hung, Y. Advances in Hazardous Industrial Waste Treatment; CRC Press: Boca Raton, FL, USA, 2009; pp. 1-35.

3. Zinck, J.M.; Wilson, L.J; Chen, T.T.; Griffith, W.; Mikhail, S.; Turcotte, A.M. Characterization and Stability of Acid Mine Drainage Treatment Sludges. Mining and Mineral Sciences Laboratories Report MMSL 96-079 (CR). MEND Project 3.42.2a, Job No. 51144, Canada. 1997. Available online: http:/ /mend-nedem.org/wpcontent/uploads/2013/01/3.42.2a.pdf (accessed on 28 April 2018).

4. Aubé, B.; Zinck, J.M. Comparison of AMD Treatment Processes and Their Impact on Sludge Characteristics; Noranda Income Technology Centre: Quebec, QC, Canada, 1999; Volume 1.

5. Kalin, M.; Fyson, A.; Wheeler, W.N. The chemistry of conventional and alternative treatment systems for the neutralization of acid mine drainage. Sci. Total Environ. 2006, 366, 395-408. [CrossRef] [PubMed]

6. Zinck, J.M. Disposal, reprocessing and reuse options for acidic drainage treatment sludge. In Proceedings of the 7th International Conference on Acid Rock Drainage (ICARD), St. Louis, MO, USA, 26-30 March 2006.

7. Chen, Z.; Wang, X.; Ge, O.; Guo, G. Iron oxide red wastewater treatment and recycling of iron-containing sludge. J. Clean. Prod. 2015, 87, 558-566. [CrossRef]

8. De Almeida, R.P.; Leite, A.D.L.; Borghetti Soares, A. Reduction of acid rock drainage using steel slag in cover systems over sulfide rock waste piles. Waste Manag. Res. 2015, 33, 353-362. [CrossRef] [PubMed]

9. Jamal, H.Y.A. Removal of Heavy Metals from Acid Mine Drainage: A Review. Int. J. New Technol. Sci. Eng. 2015, 2, 77-84.

10. Li, H.; Ji, H. Chemical speciation, vertical profile and human health risk assessment of heavy metals in soils from coal-mine brownfield, Beijing, China. J. Geochem. Explor. 2017, 183, 22-32. [CrossRef]

11. Mackie, A.L.; Walsh, M.E. Investigation into the use of cement kiln dust in high density sludge (HDS) treatment of acid mine water. Water Res. 2015, 85, 443-450. [CrossRef] [PubMed]

12. Karatza, D.; Prisciandaro, M.; Lancia, A.; Musmarra, D. Sulfite oxidation catalyzed by cobalt ions in flue gas desulfurization processes. J. Air Waste Manag. Assoc. 2010, 60, 675-680. [CrossRef] [PubMed]

13. Wang, C.Y.; Liu, J.Q.; Guo, P. An Analysis of Limestone Gypsum Desulfurization Systems; Trans Tech Publ.: Zurich, Switzerland, 2012; Volume 550-553, pp. 667-670.

14. Günther, P.; Maree, J.P.; Strobos, G.; Mtimikulu, J.S. Neutralisation of acid leachate in a coal processing plant with calcium carbonate. In Proceedings of the 8th International Congress on Mine Water \& the Environment, Johannesburg, South Africa, 20-25 October 2003.

15. Mcdonald, D.M.; Webb, J.A. Chemical Stability of Acid Rock Drainage Treatment Sludge and Implications for Sludge Management. Environ. Sci. Technol. 2006, 40, 1984-1990. [CrossRef] [PubMed]

16. O'Kelly, B.C. Sewage sludge to landfill: Some pertinent engineering properties. J. Air Waste Manag. Assoc. 2005, 55, 765-771. [CrossRef] [PubMed] 
17. Maree, J.P.; Strydom, W.F.; Adlem, C.J.L.; De Beer, M.; Van Tonder, G.J.; Van Dijk, B.J. Neutralization of Acid Mine Water and Sludge Disposal. WRC Report No 1057/1/04. 2004. Available online: http:/ / www.wrc.org.za/Knowledge\%20Hub\%20Documents/Research\%20Reports/1057-1-04.pdf (accessed on 4 May 2018).

18. Anglo American Thermal Coal. Classification and Assessment of Brine and Sludge; Report Number 1538858-298217-1; Anglo American: EMalahleni, South Africa, 2015.

19. Department of Water Affairs (DWA). Feasibility Study for a Long-Term Solution to Address the Acid Mine Drainage Associated with the East, Central and West Rand Underground Mining Basins. Study Report No. 5.5: Options for the Sustainable Management and Use of Residue Products from the Treatment of AMD. DWA Report No.: P RSA 000/00/16512/5; 2013. Available online: http:/ / sawic.environment.gov.za/ documents /2177.pdf (accessed on 22 April 2018).

20. Annandale, J.G.; Jovanovic, N.Z.; Hodgson, F.D.I.; Usher, B.H.; Aken, M.E.; Van Der Westhuizen, A.M.; Bristow, K.L.; Steyn, J.M. Prediction of the environmental impact and sustainability of large-scale irrigation with gypsiferous mine-water on groundwater resources. Water South Afr. 2006, 32, 21-28. [CrossRef]

21. Sheoran, A.S.; Sheoran, V. Heavy metal removal mechanism of acid mine drainage in wetlands: A critical review. Miner. Eng. 2006, 19, 105-116. [CrossRef]

22. Chandra, A.P.; Gerson, A.R. The mechanisms of pyrite oxidation and leaching: A fundamental perspective. Surf. Sci. Rep. 2010, 65, 293-315. [CrossRef]

23. Bortonea, I.; Chianese, S.; Ertoc, A.; Di, A.; Nardob, M.D.N.; Santonastasob, G.F.; Musmarrab, D. Risk Analysis for a Contaminated Site in North of Naples (Italy). Chem. Eng. 2015, 43, 777-780. [CrossRef]

24. Tepanosyan, G.; Sahakyan, L.; Belyaeva, O.; Maghakyan, N.; Saghatelyan, A. Human health risk assessment and riskiest heavy metal origin identification in urban soils of Yerevan, Armenia. Chemosphere 2017, 184, 1230-1240. [CrossRef] [PubMed]

25. Wen, X.; Luo, Q.; Hu, H.; Wang, N.; Chen, Y.; Jin, J.; Hao, Y.; Xu, G.; Li, F.; Fang, W. Comparison research on waste classification between China and the EU, Japan and the USA. Mater. Cycles Waste Manag. 2014, 16, 321-334. [CrossRef]

26. Lucier, C.A.; Gareau, B.J. Obstacles to preserving precaution and equity in global hazardous waste regulation: An analysis of contested knowledge in the Basel Convention. Int. Environ. Agreem. 2016, 16, 493-508. [CrossRef]

27. Johnson, D.B.; Hallberg, K.B. Acid mine drainage remediation options: A review. Sci. Total Environ. 2005, 338, 3-14. [CrossRef] [PubMed]

28. Hutton, B.; Kahan, I.; Naidu, T.; Gunther, P. Operating and maintenance experience at the eMalahleni Water Reclamation Plant. In Proceedings of the International Mine Water Conference, Pretoria, South Africa, 19-23 October 2009.

29. Steele, M.G. Throughput Improvement at the eMalahleni Water Reclamation Plant. Bachelor's Thesis, University of Pretoria, Pretoria, South Africa, 2010.

30. Loubser, G.; Verryn, S. Combining XRF and XRD analyses and sample preparation to solve mineralogical problems. S. Afr. J. Geol. 2008, 111, 229-238. [CrossRef]

31. United States Environmental Protection Agency (EPA). SW-846 Test Method 1311: Toxicity Characteristic Leaching Procedure (TCLP). 1992. Available online: https://www.epa.gov/hw-sw846/sw-846-test-method1311-toxicity-characteristic-leaching-procedure (accessed on 9 March 2018).

32. National Environmental Management: Waste Act No. 59 (2008) Waste Classification and Management Regulations. Government Gazette No. 10008; Pretoria, South Africa; 578p. Available online: https:/ /www. environment.gov.za/sites/default/ files/legislations/nemwa59of2008_wasteclassification.pdf (accessed on 9 March 2018).

33. Costley, S. Waste Classification and Management Regulations and Supporting Norms \& Standards. Waste Khoro; 2013. Available online: ttps://www.environment.gov.za/sites/default/files/docs/ wasteclassification_regulations_disposalstandards.pdf (accessed on 9 March 2017).

34. Department of Water Affairs \& Forestry (DWAF). Waste Management Series. Minimum Requirements for Waste Disposal by Landfill, 2nd ed.; 1998. Available online: http:/ / www.dwaf.gov.za/Documents/Other/WQM/ RequirementsWasteDisposalLandfillSep05Part1.pdf (accessed on 16 May 2018).

35. New South Wales Environment Protection Authority (EPA). Waste Classification Guidelines. Part 1: Classifying Waste. 2014. Available online: www.epa.nsw.gov.au (accessed on 9 March 2018). 
36. National Health and Medical Research Council (NHMRC); National Resource Management Ministerial Council (NRMMC). Australian Drinking Water Guidelines Paper 6 National Water Quality Management Strategy. 2011. Available online: https:/ /nhmrc.gov.au/about-us/publications/australian-drinking-waterguidelines (accessed on 9 March 2017).

37. New South Wales Environment Protection Authority (EPA). ACT's Environmental Standards: Assessment \& Classification of Liquid \& Non-Liquid Wastes. 2000. Available online: http:/ / www.act.gov.au/environ/ (accessed on 22 April 2018).

38. United States Environmental Protection Agency (EPA). Hazardous Waste Management System; Identification and Listing of Hazardous Waste; Toxicity Characteristics Revisions. Federal Register, Rules and Regulations; 1990. Available online: https:/ / www.epa.gov/sites/production/files/2016-04/documents/55fr11798.pdf (accessed on 9 March 2017).

39. Liu, A.; Ren, F.; Lin, W.Y.; Wang, J.Y. A review of municipal solid waste environmental standards with a focus on incinerator residues. Int. J. Sustain. Built Environ. 2015, 4, 165-188. [CrossRef]

40. Skousen, J. Overview of Acid Mine Drainage Treatment with Chemicals. In Acid Mine Drainage, Rock Drainage, and Acid Sulfate Soils: Causes, Assessment, Prediction, Prevention, and Remediation; Jacobs, J.A., Lehr, J.H., Testa, S.M., Eds.; John Wiley \& Sons, Inc.: Hoboken, NJ, USA, 2014. [CrossRef]

41. Kavouras, P.; Kaimakamis, G.; Ioannidis, T.H.A.; Kehagias, T.H.; Komninou, P.H.; Kokkou, S.; Pavlidou, E.; Antonopoulos, I.; Sofoniou, M.; Zouboulis, A.; et al. Vitrification of lead-rich solid ashes from incineration of hazardous industrial wastes. Waste Manag. 2003, 23, 361-371. [CrossRef]

42. Lin, K.L.; Chang, C.T. Leaching characteristics of slag from the melting treatment of municipal solid waste incinerator ash. J. Hazard. Mater. 2006, 135, 296-302. [CrossRef] [PubMed]

43. Mudaly, L. The Contribution of Manganese Oxides to Redox Buffering in Selected Soils of the South African Highveld. Master's Thesis, University of Pretoria, Pretoria, South Africa, 2016.

44. Feng, X.H.; Zhai, L.M.; Tan, W.F.; Liu, F.; He, J.Z. Adsorption and redox reactions of heavy metals on synthesized Mn oxide minerals. Environ. Pollut. 2007, 147, 366-373. [CrossRef] [PubMed]

45. Fischel, M.H.H.; Fischel, J.S.; Lafferty, B.J.; Sparks, D.L. The influence of environmental conditions on kinetics of arsenite oxidation by manganese-oxides. Geochem. Trans. 2015, 16, 15. [CrossRef] [PubMed] 